\title{
Dossiê Ficções científicas - arte e filosofia
}

DOI: 10.19177/memorare.v8e120212-5

A nave espacial, o alienígena, o robô, a cidade nas nuvens, a cacotopia, a paisagem inóspita sobre a qual brilham duas luas. Os tropos são claros: se você identifica algum deles, está diante de uma obra de ficção científica. Mas e se não fosse tão óbvio? E se ações mais simples da vida, tais como acordar, olhar no espelho, escovar os dentes - de repente - fossem descritas como algo maravilhoso, um passo além do prosaico? Descrever as sinapses do cérebro passando de um estado letárgico para a vigília, o ângulo como os raios luminosos incidem e são refletidos por uma superfície argêntea sensibilizando nossas córneas, a ação química do dentifrício, dissolvendo as placas bacterianas no esmalte dos dentes. Tudo isso, cada pequeno gesto banal, carrega em si um maravilhamento que pode ser decodificado e exaltado pelo olhar da ficção científica.

E se isso é verdade no aspecto menor do dia a dia, imaginem no ponto macro, como, por exemplo, o viés sociopolítico de uma sociedade? A ficção científica poderia ser um "papel tornassol" sociocultural, um "mapa" para qualquer território, uma "régua" com a qual se mensuraria... tudo? E se, por intermédio das narrativas de criadores díspares como Asimov, Bradbury, Butler, Clarke, Dick, Delany, Herbert, Vonnegut, Lem ou Le Guin, tão bem catalogadas e dissecadas por teóricos como Todorov, Jameson, Harvey ou Sodré, pudéssemos perscrutar e desvendar a pretensa realidade sensorial que nos atormenta, entender nossos anseios por um futuro melhor, mudar ou transcender nossos corpos, antecipar (e quem sabe ingerir um antídoto para) nossos desejos pervertidos por governos totalitários?

Assim, a ficção científica, seja na literatura, cinema, quadrinhos ou games, é desde o século XIX a contraparte de uma razão desmaravilhada. Enquanto o século das luzes e o progresso científico traziam a promessa de um mundo desmistificado, a ficção científica germinava na tensão entre percepções-afecções iluministas e românticas. 0 mundo descortinava-se à luz de um saber que também ocultava esse mundo do que ele sabia de si ou do que sabíamos por completo dele. A janela convertia-se em espelho e vice-versa, o mundo científico representado tornava-se novamente maravilhoso por segredos inerentes a uma tecnologia desconhecida e as maravilhas utópicas ou distópicas - revelavam-se gratificante ou terrivelmente reais como fábulas do hoje.

De Luciano de Samósata, Cyrano de Bergerac e Voltaire, passando por Mary Shelley, Júlio Verne e H. G. Wells, e chegando a Stanley Kubrick, Moebius e China Miéville. Passeando ou apenas dando uma volta ao redor da Lua de Luciano, Cyrano, Verne e Wells, habitada por criaturas críticas à humanidade. Conhecendo Micrômegas. Acompanhando a trilha de corpos deixada por cadáveres redivivos, criaturas letradas que assombram, perseguem e assassinam seus criadores. Fugindo do destino gravado por máquinas que nos odeiam. Conhecendo as múltiplas versões de um mesmo personagem criado 
por Dick ou Le Guin, as cidades paralelas de Miéville, coexistentes no tempo, mas não no espaço - metáforas quase poéticas de nossas pluralidades políticas e sociais. Visitando as urbes com arquiteturas transtemporais, como a Capital de Mongo, de Alex Raymond, a NeoTokyo, de Katsuhiro Otomo, ou as plagas de Paralelas, de Watson Portela. Caminhando pelos vastos desertos de Moebius, de relevos acidentados, formas abstratas e populações alienígenas, paisagens tão exóticas que estão sempre no limiar do extraterrestre, e que ao mesmo tempo retratam a experiência impactante, o choque cultural e o contato com alucinógenos que o autor teve em sua juventude vivendo no México.

Acrescenta-se também a ficção científica abordada pela filosofia. Através de autores como Friedrich Nietzsche, Hans Vaihinger, Martin Heidegger, Vilém Flusser, Jean Baudrillard, entre outros, a ficção científica não se restringe tão somente a um gênero literário-artístico, mas é também uma questão epistemológica e um pressuposto metodológico do fazer ciência. Deste modo, a ficção, outrora antítese contra-factual, torna-se um operador da ciência, convergindo a filosofia da ciência com a teoria estética.

Diante dessa dupla potência fabulatória de pensar - e, às vezes, transformar - o real e sobre ele especular, o dossiê traz artigos e tradução de pesquisadores advindos de diferentes disciplinas que contribuíram com produções inéditas, propondo investigações e trazendo novas perspectivas sobre essa que é a mais racional (e também talvez a mais transcendente) das ficções.

Em “A 'ficção científica' em Vilém Flusser: alguns caminhos de investigação", Jessé Antunes Torres explora a proposta de Vilém Flusser para uma ficção científica, evidenciando a genealogia desse conceito e pensando a ficção científica como uma estratégia da ciência. Em "Existências imaginadas: a consciência de si na série televisiva Westworld", Suzinara Strassburger Marques e Rosane Maria Cardoso partem da análise das personagens da série Westworld com o objetivo de compreender como se desenvolve o processo de percepção de consciência de si em humanos e androides. Em "Expanded universes in science fiction: a matter of integration", Arthur Maia Baby Gomes e Elaine Barros Indrusiak buscam explicar como se constituem os universos expandidos nas produções culturais de ficção científica a partir do conceito de "mecanismos de integração". Em "Sobre diversidades e regionalidades: a ascensão da Quarta Onda da ficção científica brasileira", Alexander Meireles da Silva defende a hipótese de que a ficção científica brasileira vive sua Quarta Onda a partir da celebração das diversidades socioculturais e regionais do Brasil, mais especificamente pelo afrofuturismo, amazofuturismo e sertãopunk. Em "Real and semi-real - an architectural backstory for Flusser's dual scientific fictions", William Hanff explora duas abordagens de Vilém Flusser para a ficção científica, conectando-as com a filosofia de Hans Vaihinger e analisando a história em quadrinhos "As cidades obscuras", de modo a propor uma arquitetura das novas mídias.

Em "Entre distopia, realismo mágico e ficção científica: o problema do gênero no roteiro cinematográfico não filmado inédito de A hora dos ruminantes", Marcelo Cordeiro de Mello discute o problema 
do gênero e a relação entre a ficção científica e o realismo mágico no projeto cinematográfico não filmado de A hora dos ruminantes, de 1967, adaptado da obra homônima do escritor José J. Veiga pelo cineasta Luiz Sergio Person e o crítico de cinema e roteirista JeanClaude Bernardet. Em "O inimigo objetivo em distopias pós-11 de Setembro: uma análise de Holy Terror: Terror Sagrado e Jogos Vorazes", Monique Heloísa de Souza e Murilo Ariel de Araujo Quevedo trabalham o conceito de Hannah Arendt de "inimigo objetivo" em duas obras de mídias distintas e desenvolvem como as mesmas ajudam a pensar a Terceira Onda da ficção científica pós-11 de setembro e o nacionalismo estadunidense. Em "Ficção científica e imagens de eufemização: uma relação entre Arte e Imaginário através do filme Solaris, de Andrei Tarkovski", Heloisa Juncklaus Preis Moraes, Luiza Liene Bressan e Ana Caroline Voltolini Fernandes relacionam o filme Solaris, de Tarkovski, com a teoria do imaginário de Gilbert Durand, destacando convergências entre a produção artística, vivências cotidianas e questões existenciais. Em "Regime de tempo no afrofuturismo a partir dos quadrinhos do Pantera Negra”, Micaella Schmitz Pinheiro analisa o regime de tempo que circunscreve a poética afrofuturista nos quadrinhos do personagem Pantera Negra a partir dos conceitos de "cronos" e "aion" de Gilles Deleuze.

Em "O cyberpunk ocidental e oriental: as distâncias textuais entre Blade Runner e Tetsuo", Ricardo Jorge de Lucena Lucas e Lucas Bernardo Reis buscam investigar as diferenças conceituais e epistemológicas entre o cyberpunk ocidental e oriental na história em quadrinhos "The long tomorrow", o filme Blade Runner, a arte EroGuro e o filme Tetsuo. Em "A comunidade do não-lugar: William Morris e utopias passadas e futuras", Rafael Silva Fouto analisa duas obras de ficção científica de William Morris comparando-as com os conceitos de comunidade, imunidade, arte e revolta conforme trabalhados pelos filósofos Jean-Luc Nancy, Roberto Esposito, Jacques Rancière e Furio Jesi. Em "A guerra dos mundos virada do avesso: a metáfora política do novo coronavírus", Lucas Victor de Oliveira Araújo e Rosanne Bezerra de Araújo estabelecem uma relação entre a ficção científica de H. G. Wells e as guerras e surtos de peste nos séculos posteriores, podendo servir inclusive para tecer comentários sobre a pandemia de Covid-19 com base em autores como Slavoj Žižek e Valentin Volóchinov. Em "A ficção científica de acordo com os Futurians”, Andreya Susane Seiffert analisa o legado e visão de mundo do importante The Futurian Society of New York, grupo de fãs, escritores e editores que existiu entre 1938 e 1945 e fez contraponto à Astounding Science Fiction de John Campbell Jr. Em "Potências do tempo na ficção científica em quadrinhos: pós-futurismo, antifuturismo e retrofuturismo", Alexandre Linck Vargas investiga como o fim do futuro em 1977 segundo Franco Berardi altera a poética da ficção científica e repercute diferentemente na produção em quadrinhos britânica, franco-belga e italiana. Por fim, contamos com a tradução de Renan Kenji Hayashi do importante e até então inédito em língua portuguesa conto de ficção científica "Bokko-chan" (1963), de Shinichi Hoshi.

Esperamos, a partir de uma seleção bastante rica e diversa de olhares, que este dossiê seja de grande contribuição, provando que as 
"ficções científicas", em sua pluralidade literária, artística e filosófica, são, acima de tudo, a potência de especular.

Organizadores

Dr. Alexandre Linck Vargas (UNISUL)

Dr. Octavio Aragão (UFRJ) 